\title{
Still working for the man? Women's employment experiences in Australia since 1950
}

\author{
Glenda Strachan
}

\begin{abstract}
This article tackles the question of what is the 'good life' for women in employment in Australia through an examination of national legislation and policies. Since 1950 what has been seen as the good life has changed dramatically. The article outlines three phases of change: in the 1950s and 1960s men were regarded as the wage earners and women the homemakers, with women barred from some jobs and paid less than men; in the 1970s legislation and equal pay cases removed overt discrimination against women; from the mid 1980s the complexity of achieving equality for women at work was recognised through equal opportunity legislation, work and family policies and equal pay inquiries. In 2010 the 'good life' for women is having the same opportunities and outcomes in employment as men. While policy provisions support this, the reality of achieving this is difficult. So in 2010 many women are still 'working for the man' in the context that most managers are men.
\end{abstract}

Keywords: women's work; Australian history; equal opportunity 


\section{Introduction}

What does the 'good life' mean in relation to employment, and in particular women's participation in employment in Australia? Each individual might have a different view of this, and their view of the good life at work might vary across their life time. In addition, not all women want the same thing because the category of women, just like the category of men, is composed of women from different cultural backgrounds, different levels of education and so on, all of which shapes a view of what is desired. Nevertheless, we can look to national policies in an attempt to see what the good life is for women in employment. These policies reflect the views of many in the community (though never all), and were the product of struggle by sections of the community. In addition, as Australia is a signatory to many international treaties, current policies respond to directives such as the 1979 United Nations Convention on the Elimination of all Forms of Discrimination Against Women (United Nations 2010).

National policy, as seen through legislation and industrial case decisions, has undergone major changes in Australia over the past six decades. In the 1950s the ideal was full employment for men in full-time work (Firth 2004) and there was legally sanctioned discrimination against women. Women in the workforce were segregated into specific jobs, barred from some, and usually paid less than men for the same job. While women formed the essential workforce in some occupations, their paid work was regarded as subsidiary to that of men, as women's primary role was that of housewife and mother. In the twenty-first century equality at work between the sexes is a national goal: anti-discrimination legislation, equal pay provisions in industrial legislation and equal opportunity legislation designed to promote women's participation in all sectors of employment paint a picture different from the 1950s (Strachan, Burgess and Henderson 2007). Women and men are both legitimate workers, and there should be no difference in the opportunities for work, the options which face them, and the remuneration and benefits received. This outlook is a dramatic change in what national policy agrees is the good life for women in employment: women have more options in employment than they had in 1950 and equal opportunity - equal with men - underpins legislation. Of course, achieving this equality, after decades of inequality, is a not an easy proposition.

This change has taken place across three generations of women. The women of the 1950s were predominantly home makers and ceased employment on marriage or the birth of their first child. Their daughters entered employment in the 1970s and 1980s and benefited from the changes to policies of no discrimination in employment on the grounds of sex and equal pay, achievements which were fought for by many of their mothers (Lake 1999: 214-230). Two-thirds of the daughters of the homemakers of the 1950s, that is the women born from 1946 to 1966, are still in the workforce (ABS 2009). The grand-daughters of the women of the 1950s have entered the workforce since the 1990s and found a landscape with legislation to promote equal opportunity for women in employment - a landscape that is totally different from that of 
their grandmothers. Many of these young women would not know what the 'marriage bar' was - a phenomenon well known to their grandmothers that prevented married women from having permanent employment in the public service and some private companies.

Over the course of six decades there has been a major shift in Australian society from one where women's primary role was in the private sphere of the home and family care to one where women's lives revolve around both paid work and family care. This article outlines three phases in this change: the 1950 s and 1960s were characterised by overt discrimination against women at work; the 1970s by the removal of overt discrimination; and since the mid 1980s there has been a recognition of the complexity of delivering equal opportunity for women at work with resultant policies that attempt to tackle this multifaceted issue. The title of this article, 'still working for the man', alludes to the fact that most women in the 1950s worked in the home caring for their husband. In 2010, many women can still be seen as working for the man as most women work for a male manager. Legal provisions for equal opportunity have not translated into reality for all women, particularly those aspiring to senior managerial positions, and gender segregation of jobs remains a feature of Australia's labour market.

\section{Women at Work in the 1950s}

The role of women as wives and mothers predominated in Australian society in the 1950s when most women worked until they married, and following marriage and the birth of their first child, focused on the care of husband, children and the home. While at work, women were employed in industries and occupations that society saw as 'suitable'. Women cared for others as nurses, teachers, secretaries and domestic workers. If they worked in the same job as a man, they usually took home 75 per cent of their male co-workers' wage. Few women managed men in the workplace.

Women in the 1950s vividly remembered the previous decade which encompassed the long years of World War II (1939-1945) and the subsequent years of hardship and rationing. The war years saw a dramatic policy change on the position of women in paid employment. In 1942 manpower regulations required women who did not have the primary responsibility for the care of children or other relatives to work outside the home, even if they were married and keeping house. A contemporary newsreel exhorted viewers by saying if the cautious see major post-war problems growing out of the wholesale transfer of women to male jobs, there can be but one answer to them: war stands on no ceremony, and this war we must win - no matter how our social structure may suffer in its winning' (McMurchy, Oliver and Thornley 1983, 110). By 1944 women formed 25 per cent of the workforce, with almost one-third of all women aged fifteen to 65 in paid employment. While most women remained in 'traditional' occupations such as nursing and retailing, some women entered previously male domains such as engineering manufacture. Yet the dominant ideology and the belief that women's primary place was in the home did 
not change. On numerous occasions governments and trade unions stressed that, in peace time, society would return to the way it had been before the war (Strachan 1996: 152-157). As E.C. McGrath, federal secretary of the Printing Industry Employees' Union, predicted, 'a belief which any woman may hold that she will be able to retain her industrial position is likely to bring unfortunate disillusionment to her' (McGrath 1943: 39).

At the end of the war the traditional gender division of jobs was re-asserted. Service personnel had automatic preference for post-war employment and reinstatement in their pre-enlistment positions and 'the predominantly male trade unions were determined that women would be pushed out of "male" industries' (Allport 1984: 18). Of course the preferences of women themselves varied. Surveys during the war showed that women wanted to continue working (Allport: 19). On the other hand 'many women were simply tired', having endured long hours in frequently monotonous jobs, 'the second shift of domestic work', inadequate child-care, food, clothing and petrol rationing, and often additional voluntary work. So 'if a newly returned husband was able to support them... there were many women who were only too glad to have their work-load lightened' (McMurchy, Oliver and Thornley 1983: 114). The result was an increase in births, the 'baby boom', with the total fertility rate reaching 3.5 babies per woman in 1961 (ABS 2008a: 199), and emphasis on the nuclear family.

Post war governments were acutely short of labour and turned to married women (Nolan 2003: 80). In 1947 married women formed 19.8 per cent of the female workforce, 34.3 per cent in 1954, and 42 per cent in 1961. By 1961 women formed a quarter of the labour force (Sheridan and Stretton 2004: 86). Despite these changes, unease remained over the 'proper' role of women. For example, in 1956 readers of the popular magazine Women's Day were six-to-one against married women working, largely on the grounds of what constituted the best interests of children (Sheridan and Stretton: 85). In contrast, throughout the 1940s and 1950s women's groups argued for equality for women (Lake 1999: 191-213).

Gender segregation remained an enduring feature of the labour market. In 1961 one quarter of all employed women were stenographers and clerks, with a further 11 per cent shop assistants, 6 per cent nurses, 5 per cent teachers and 4 per cent textile machinists (Sheridan and Stretton 2004: 85). The segregation in levels of women's work can be seen clearly in an analysis of the Commonwealth Public Service (CPS): in 1961 almost 34,000 women were in the CPS, half with permanent status and half with temporary status. Over 92 per cent were in the Fourth Division, the lowest, with the remainder in the Third Division. Only 2,500 of these women were married, all on temporary status (Sheridan and Stretton 2004: 87). Most women were paid 75 per cent of the male rate (Bahnisch 2000: 22-23; Basic Wage Inquiry 1950: 840). 


\section{Women at Work in the 1970s}

By the time the daughters of the women setting up households in the 1950s entered the workforce in the 1970s, this generation of women had expanded employment options. With increasing numbers of women in the workforce, social attitudes towards women's paid work began to change and many women called for change (Lake 1999: 214-252; Patmore 1991: 161-183). The fertility rate dropped rapidly to 2.9 babies per woman in 1969 , reducing to 2.1 babies in 1976 and it has remained below this ever since (ABS 2008a: 199). By 1970 the female labour force participation rate was 38.6 per cent. Shortages of teachers, propelled by the increased birth rate and increased length in education, forced a reconsideration of the marriage bar which existed in all public services, instrumentalities such as the Commonwealth Bank and local government. The marriage bar was removed for teachers in New South Wales in 1947 and Victoria in 1956 (Nolan 2003: 84; Dwyer 2006). However, despite labour market shortages in public services and activism by women the marriage bar remained in place in the federal public service and all other states until 1966 (Sheridan and Stretton 2004). In Queensland the retention of the marriage bar was supported by the major public service union on the grounds of 'support for the employment of single females; the loss of opportunities for men; prevention of child delinquency; and defense of the ideals of marriage and the interests of the Australian nation' (Colley 2004: 80).

The decade of the 1970s brought many changes which removed overt discrimination against women. The increased presence of women in the workforce, combined with the nascent civil rights and women's movement, increased calls for equality at work. Against this backdrop, trade unions initiated and led successful equal pay cases, most influentially in the Commonwealth Conciliation and Arbitration Commission in 1969 and 1972. The 1969 case formulated the principle of equal pay for equal work but Principle 9 stated that 'equal pay should not be provided... where the work in question is essentially or usually performed by females but is work upon which male employees may also be employed' (Equal Pay Case 1972), a criterion which, given gender segregation of the workforce, meant few women benefited. For instance, female nursing staff in the Australian Capital Territory were denied equal pay with their male colleagues on the basis that 'it would be illogical to raise the wages of some 700 people to the level paid to approximately $7 \ldots$ merely on the grounds that equal pay should be provided for equal work' (Department of Labour and National Service 1972). Only 18 per cent of female employees benefited from this decision (O'Donnell and Hall 1988: 54).

The equal pay case concluded in December 1972 awarded women workers 'equal pay for work of equal value' and removed Principle 9. The potential coverage of this judgment was estimated to be one and a half million women workers out of a female workforce of 1,795,000 (Ryan and Conlon 1989: 162). However, equal pay was not mandatory and the pursuit of equal pay occurred on an ad hoc basis, relying on individual trade unions to institute cases. In 
the actual implementation of the 1972 case, there were very few assessments of the nature of work. Generally, employers and unions merely agreed on the integration of male and female classifications without any empirical studies of work valuation and comparison, such as job evaluation (Short 1986: 325). The historical undervaluing of women's work remained. Given the high levels of gender segregation, 'as all wages at the beginning of this [twentieth] century reflected sex discrimination, it is highly likely that the original rates for jobs such as nursing were discriminatory' (Short: 329). Despite the case by case implementation of equal pay, Australia's female to male earnings ratio increased faster in the 1970s than that of any other country, from around 0.60 to 0.80 in six years (Burgess et al. 1998).

From 1975 the federal and state governments began enacting anti-discrimination legislation. Today, specific legislation targeting sex discrimination comes from the federal Sex Discrimination Act 1984 and state anti-discrimination legislation (Ronalds 2008). The purpose of the Queensland Anti-Discrimination Act 1991, for example, is to 'promote equality of opportunity for everyone by protecting them from unfair discrimination in certain areas of activity and from sexual harassment and certain associated objectionable conduct.' It prohibits discrimination on grounds including sex, relationship status, pregnancy, parental status, breastfeeding, family responsibilities, as well as age, race and impairment. Individuals and groups of women (often through their trade union) are able to pursue remedies after an alleged case of discrimination, although taking this course of action can be extremely difficult for an individual complainant (Scutt 1990: 76). Nevertheless, the legislation acknowledged publicly that society would no longer accept women as second class citizens thereby denying them access to many benefits available to men (Department of Prime Minister and Cabinet 1984: 13).

\section{The 1980s and Beyond}

Legislation and industrial cases up to the mid-1980s sought to remove overt discrimination against women in employment. The newly-elected Labor Government argued that this was not enough to ensure that women achieved equality with men in employment (Ronalds 1991: 8-26). A policy discussion paper issued in 1984 proclaimed that 'anti-discrimination policies, important as they are, cannot by themselves improve women's position in the labour market, totally open up a greater range of jobs to women, nor ensure that women can compete on equal terms with men for promotion' (Department of the Prime Minister and Cabinet 1984: 1). Legislation designed to promote equal employment opportunity (EEO) was introduced. The federal Affirmative Action (Equal Opportunity for Women) Act 1986 (replaced by Equal Opportunity for Women in the Workplace Act 1999 and with similar legislation for the public services) is unique to Australia. In the Australian context, Affirmative Action 'is about achieving equal employment opportunity for women... [and] to achieve this goal, the barriers in the workplace which restrict employment and promotion opportunities for women have to be systematically eliminated' (Affirmative Action Agency 1990: 1). The Act compels organisations with more 
than one hundred employees to devise and implement an EEO program, based on analysis of the specific issues pertaining in each organisation. The focus is towards individual enterprise responsibility rather than legislating for minimum standards and conditions (Strachan, Burgess and Henderson 2007). Since the 1990s ideas of managing diversity have been added to this mix. While there is no agreed definition of what this means in an organisation, it broadly covers organisational policies and practices which maximise the use of diverse characteristics of employees for the benefit of the business (Strachan, French and Burgess 2010; French, Strachan and Burgess 2010).

From the 1990s 'work and family' policies have been discussed widely (for example, Goward et al. 2005; Pocock 2003; Charlesworth, Campbell and Probert 2002). This term is used to cover organisational policies that assist employees to combine paid work and personal caring responsibilities, and the work and family rhetoric has been taken up by government, business and trade unions (Burgess and Strachan 2005). For example, in 1993 Ralph Willis, treasurer in the Labor Government, asserted that 'the smart employers are ones who recognize, understand and respond to the fact that working women and working men have family responsibilities' (Crowley and Willis 1993). This discussion clearly marks the change from male single breadwinner to a dual income earning model in Australia. In the 1950s the conundrum of a family unit earning an income and caring for the family was organised through the model of the male wage earner and the woman as home carer. By the 1990s this model had broken down with greater numbers of women in the workforce so the question of how family units managed both responsibilities became a matter for debate.

There has been little underpinning of these policies by legislation hence access to them varies widely. Since 2009 minimum conditions in the Australian Fair Pay and Conditions Standard include 10 days annual personal/carer's leave for most full-time workers. Parental leave provisions in industrial legislation give 52 weeks unpaid leave for the primary carer for most permanent and some casual workers (Australian Government Workplace Authority 2008). Some enterprise agreements provide paid leave: one study found that 59 per cent of agreements in the public sector in 2007, but only 16 per cent in the private sector, provided paid leave, with 14 weeks being the most common period for paid maternity leave (Baird, Frino and Williamson 2009). Home based employment, job sharing and assistance with or access to childcare remain scarce. The major item in enterprise agreements has been the deregulation of working time (increased spread of normal hours, loss of penalty rates, work at call and unpredictable hours) often extending employer discretion over working hours. Many of these policies exist in internal organisational documents alone and not in other agreements and therefore access to them is discretionary (Burgess and Strachan 2005). Who has access to these arrangements? It depends on the organisation, but 'flexible work arrangements are positively associated with higher earnings, professional and paraprofessional and clerical/ sales... occupations, structured human resources management in organisations, written EEO policies, public sector organisations, and number of employees' 
(Hall 2003). The juxtaposition of these policies with major changes such as increased hours and greater organisational flexibility expressed in longer working days, longer working week, increased numbers of part-time and casual workers, may make it difficult for women and their partners to accommodate both paid work and family care (Strachan, Burgess and Henderson 2010; ACTU 2004: 10).

Since the 1980s trade unions and the women's movement have continued to press for a re-examination of the historical undervaluing of women's work. These efforts bore fruit with pay equity inquiries in several states, beginning with New South Wales in 1998. The outcomes from the 2001 Queensland inquiry, for example, included the principle that a direct comparator is not needed for the assessment of work. The Commission can consider the impact of the gender of workers on remuneration levels including whether sufficient and adequate weight has been placed on the typical work performed and the skills and responsibilities exercised by women as well as the conditions under which the work is performed and other relevant work features (QIRC 2002). Despite these significant changes in the understanding of women's wages, few changes actually occurred although specific cases have raised the wages and improved the conditions of Dental Assistants and Child Care workers (QIRC 2007: 35-38). A further inquiry reported in 2007 and its recommendations include a specific Pay Equity Act with the principal aim of achieving pay equity through the promotion of equal opportunity and the prevention of discrimination, including the requirement that employers prepare pay equity plans (QIRC 2007). By 2010, moves have not been made to introduce such an Act, and in 2009 the federal government conducted its own inquiry (House of Representatives Standing Committee on Employment and Workplace Relations 2009).

While the exact pay gap differs dependent on the exact unit measured, it remains persistently high. For example, when looking at average weekly ordinary time earnings, women earn 84 per cent of male earnings with the largest difference occurring in the finance and insurance industry where women's earnings are two-thirds (66 per cent) those of men. Men have higher average earnings than women in every industry and occupation group (ABS 2008a: 254-256). As enterprise bargaining has become the primary avenue for wage determination, bargaining is decoupled from industry wide awards, and wider comparability mechanisms are marginalised (Green 1996). Moves towards individual bargaining under federal industrial legislation from the late 1990s further increased the vulnerable position of women workers (Queensland Government 2006: chapter 3), thus increasing both the need for, and complexity of delivering, equal pay.

The reasons for the pay gap are long-standing: women are more likely than men to make adjustments to their work pattern because of caring and family responsibilities and hence their working lives are more discontinuous than men's. Women spend less time in the paid workforce than men; they are more likely to work part-time or on a casual basis; are more likely to 
have interrupted career patterns than men due to childbirth and caring responsibilities; they remain concentrated in low paid occupations and industries; they are less likely to be paid overtime than men. The 'resilience of the pay gap over time' suggests 'multiple and deeply entrenched causal factors' within and outside the labour market including occupational segregation, undervaluation of traditional women's work and organisational culture and practice, and the gendered division of domestic labour (Whitehouse 2004). The earnings gap has implications not only during working life but into retirement, as superannuation holdings for women are approximately a third of that for men (Office for Women 2008).

\section{Women's Work in the Early Twenty-First Century}

In contrast to the women of the 1950s, at the beginning of the twenty-first century most women's lives revolve around both paid work and family care. Younger women in the workforce today are the most highly educated cohort Australia has seen, and more women (28 per cent) in this group (born 1966-1986) have university degrees than men (21 per cent) (ABS 2008b). In 2006-2007, the female labour force participation rate was 57.6 per cent, compared with 72.2 per cent for men. A large component of the growth in female employment has been part-time work, with 44.8 per cent of employed women working on a part-time basis, compared to 15.2 per cent of men. Much part-time work is done on a casual (temporary) basis which means lack of security of tenure in the job and no access to many leave entitlements, and women are more likely to be represented in this category than men (24.6 of women workers compared with 15.6 per cent of male workers) (ABS 2008a: 223-230).

Women are having fewer children and doing so later in their lives. In 2005 the total fertility rate was 1.79 babies per woman (ABS 2008a: 199). The predominant family pattern (44 per cent of families) is two parents with two incomes while about 23 per cent of families have a single parent. In 200051 per cent of couple families had both partners employed. The husband was employed in 89 per cent of all couple families with dependants with 95 per cent working full time. The wife was employed in 61 per cent of couple families with dependants, 26 per cent on a full time basis, a rise from 20 per cent in the early 1980s. The majority of one parent families with dependants (86 per cent) were headed by women, 49 per cent of whom were employed (ABS 2000).

An increased presence by women in the labour market has not necessarily been associated with a reduction in gender segregation (Burgess, French and Strachan 2010). For the first seventy years of the twentieth century between 55 per cent and 75 per cent of women were employed in occupations where more than half of the workers were women (Power 1975). Although the most common women's occupations have changed, a high level of segregation remains. Two-thirds of all women workers are employed in clerical or sales and service positions. In addition to occupation, women are segregated by industry with women predominating in health and education (more than 70 
per cent of employees) and forming less than a quarter of the workforce in mining, construction, transport and manufacturing (Office for Women 2008). In addition, vertical segregation, that is the level in the organisation, remains. Women are grossly under-represented in management, especially senior management. For example, there has been little or no increase in the percentage of women in senior positions in ASX companies since 2004 (see Table 1). A comparison with four other countries (USA, Canada, UK and South Africa) reveals that Australia compares unfavourably, and the percentage for female ASX200 executive managers in Australia is the lowest in all these countries (EOWA 2008). This is but one example - many other labour force statistics could be used.

Table 1: Women in Management in Australia, 2004-2008

\begin{tabular}{llll}
\hline & $\begin{array}{l}\mathbf{2 0 0 4} \\
\text { \% women }\end{array}$ & $\begin{array}{l}\mathbf{2 0 0 6} \\
\text { \% women }\end{array}$ & $\begin{array}{l}\mathbf{2 0 0 8} \\
\text { \% women }\end{array}$ \\
\hline ASX200 chairs & 1.1 & 2.0 & 2.0 \\
\hline ASX200 CEOs & 2.3 & 3.0 & 2.0 \\
\hline ASX200 board directors & 8.6 & 8.7 & 8.3 \\
\hline ASX200 exec. managers & 10.2 & 12.0 & 10.7 \\
\hline Managers \& professionals & 44.4 & 44.2 & 45.5 \\
\hline
\end{tabular}

Source: EOWA (2008, 2006, 2004).Conclusion

The changes in Australian society since 1950 have been profound. From a minority of women in paid work in 1950 , it is now the norm to combine both paid work and family care across the life course. The reality of the male breadwinner exists in a minority of families, as both women and men contribute to the family funds in the majority of households. Major changes have occurred in the conditions of work for women. Whereas lower wages for women were the law in 1950, this is now forbidden through anti-discrimination and industrial legislation. Equal opportunity at work and equality of conditions and rewards are now the law.

What kind of working world do the grand-daughters of those women of the 1950s face? They are the most highly educated cohort with more women than men possessing university degrees. They will spend longer than their grandmothers in the paid workforce and can enter any occupation and industry and expect equal pay with their male co-workers. They can expect organisations (at least those with more than 100 employees as set out in the legislation) to have employment equity programs that consider and address equity issues. What is the current reality at work? There are many more opportunities for women to enter the workforce but these opportunities decrease if women choose to move to managerial ranks. Most managers are men. Women may be constrained in their choices by hostile organisational cultures and lack of practices that assist with managing both paid work and family care. Are women still working for a man? Most probably. 


\section{References}

ABS (Australian Bureau of Statistics) (2009) A Picture of the Nation: The Statistician's Report on the 2006 Census, Cat. No. 2070.0, Canberra: ABS.

ABS (2008a) 2008 Year Book Australia, Cat. No.1301.0, Canberra, ABS.

ABS (2008b) A Picture of the Nation: The Statistician's Report on the 2006 Census, Cat. No. 2070.0, Canberra: ABS.

ABS (2000) 'Labour Force Status and Other characteristics of Families', Cat. No. 6224.0, Canberra: ABS.

ACTU (Australian Council of Trade Unions) (2004) 'Work and Family Test Case 2004: ACTU Outline of Contentions', available at <http://www.actu. asn.au/Publications/Archive/Papers/WorkAndFamilyTestCase2004ACTUOu tlineOfContentions.aspx>, accessed 18 January 2010.

Affirmative Action Agency (1990) Taking Steps: Employers' Progress in Affirmative Action, Canberra: AGPS.

Allport, C. (1984) 'Left off the Agenda: Women, Reconstruction and New Order Housing', Labour History, 46, 1-20.

Australian Government Workplace Authority (2008) 'Leave', available at $<$ http://www.workplaceauthority.gov.au/conditions-of-employment/leave. asp>, accessed 9 March 2008.

Bahnisch, M. (2000) History of Pay Equity in Queensland, Queensland Government Submission to Pay Equity Inquiry, No 11568 of 2000, available at <http://www.deir.qld.gov.au/pdf/ir/payequitya1.pdf $>$, accessed 20 July 2009.

Baird, M., Frino, B. and Williamson, S. (2009) 'Bargaining for paid maternity and paternity leave: An analysis of enterprise agreements in Australia, 2003-2007', in J. Lewer, S. Ryan and J. Macneil (eds), Labour, Capital and Change: Proceedings of the $23^{\text {rd }}$ AIRAANZ Conference, Volume 2, Newcastle, NSW: AIRAANZ.

Basic Wage Inquiry (1950) Commonwealth Arbitration Reports, 68.

Burgess, J., Croce, N., Denniss, R., Green, R. and Strachan, G. (1998)

Statement by the Employment Studies Centre, University of Newcastle, to NSW Pay Equity Inquiry.

Burgess, J., French, E. and Strachan, G. (2010) 'Workforce and Workplace Diversity in Australia', in G. Strachan, E. French and J. Burgess, (eds), Managing Diversity in Australia: Theory and Practice, Sydney: McGraw Hill, 17-39.

Burgess, J. and Strachan, G. (2005) 'Integrating Work and Family

Responsibilities: Policies for Lifting Women's Labour Activity Rates', Just Policy: A Journal of Australian Social Policy, 35, 5-12. 
Charlesworth, S., Campbell, I. and Probert, B. with Allen, J. and Morgan, L. (2002) 'Balancing Work and Family Responsibilities: Policy Implementation Options', Report for the Victorian Departments of Premier and Cabinet and Innovation, Industry and Regional Development, Melbourne: Centre for Applied Social Research, RMIT University.

Colley, L., (2004) 'Merit is in the Eye of the Beholder: Barriers to Female Employment in the Queensland Public Service from 1859-1959', Journal of Interdisciplinary Gender Studies, 9 (1), 62-89.

Crowley, R. and Willis, R. (1993) Smart Companies, Smart Policies, Joint News Release, 1 December.

Department of Labour and National Service (1972) Equal Pay: Some Aspects of Australian \& Overseas Practice: Supplement, September, Department of Labour and National Service, np.

Department of Prime Minister and Cabinet (1984) Affirmative Action for Women, vol. 1, Canberra: AGPS.

Dwyer, D. (2006) 'Justice at last? The Temporary Teachers Club and the Teaching Service (Married Women) Act 1956', Labour History, 91, 151168.

EOWA (Equal Opportunity for Women in the Workplace Agency) (2008) EOWA 2008 Australian Census of Women in Leadership, available at <http://www.eowa.gov.au/Australian_Women_In_Leadership_Census/2008_ Australian_Women_In_Leadership_Census/Media_Kit/EOWA_ Census_2008_Publication.pdf>, accessed 20 July 2009.

EOWA (2006) 2006 EOWA Australian Census of Women in Leadership, available at <http://www.eowa.gov.au/Australian_Women_In_Leadership_ Census/2006_Australian_Women_In_Leadership_Census/2006.asp>, accessed 20 July 2009.

EOWA (2004) 2004 EOWA Australian Census of Women in Leadership, available at <http://www.eowa.gov.au/Australian_Women_In_Leadership_ Census/2004_Australian_Women_In_Leadership_Census.asp $>$, accessed 20 July 2009.

Equal Pay Case (1972) Commonwealth Arbitration Reports, 147.

Firth, A. (2004) 'The Breadwinner, his Wife and their Welfare: Identity, Expertise and Economic Security in Australian Post-War Reconstruction', Australian Journal of Politics and History, 50 (4), 491-508.

French, E., Strachan, G. and Burgess, J. (2010) 'Approaches to equity and diversity in Australia: Conflicting beliefs and competing ideals', in G. Strachan, E. French and J. Burgess, (eds), Managing Diversity in Australia: Theory and Practice, Sydney: McGraw Hill, 41-56.

Goward, P., Mihailuk, T., Moyle, S., O’Connell, K., de Silva, N., Squire, S., and Tilly, J. (2005) Striking the Balance: Women, men, work and family. Discussion Paper 2005, Sydney: HREOC. 
Green, R. (1996) 'The "Death" of Comparative Wage Justice in Australia', Economic and Labour Relations Review, 7 (2), 224-243.

Hall, P. (2003) Work and Family Issues - Trends and Projections, NSW Department for Women, available at<http://www.women.nsw.gov.au/PDF/ Archived/Work\%20and\%20Family\%20Issues.pdf>, accessed 18 January 2010.

House of Representatives Standing Committee on Employment and Workplace Relations (2009) Making it Fair: Pay Equity and associated Issues Related to Increasing Female Participation in the Workforce, Canberra: Parliament of the Commonwealth of Australia < http://www.aph.gov.au/house/ committee/ewr/payequity/report/chapter1.pdf>, accessed 23 January 2010.

Lake, M. (1999) Getting Equal: The History of Australian Feminism, Sydney: Allen and Unwin.

McGrath, E. (1943) 'The Future of Women in Industry', Australian Quarterly, 15 (2), 39-45.

McMurchy, M., Oliver, M. and Thornley, J. (1983) For Love or Money: A Pictorial History of Women and Work in Australia, Ringwood, Vic: Penguin.

Nolan, M. (2003) 'The high tide of a labour market system: The Australasian male breadwinner model', Labour and Industry, 13 (3), 73-92.

O’Donnell, C. and Hall, P. (1988) Getting Equal: Labour Market Regulation and Women's Work, Sydney: Allen and Unwin.

Office for Women (2008) Statistical Snapshot, Brisbane, Office for Women, Queensland Government, available at <http://www.women.qld.gov.au/ resources/statistical-snapshot>, accessed 20 July 2009.

Patmore, G. (1991) Australian Labour History, Melbourne: Longman Cheshire.

Pocock, B. (2003) The Work/Life Collision, Sydney: Federation Press.

Power, M. (1975) 'Women's Work Is Never Done by Men: A Socio-economic Model of Sex Typing in Occupations', Journal of Industrial Relations, 17 (2), 225-239.

QIRC (Queensland Industrial Relations Commission) (2002) Equal Remuneration Principle, No B450 of 2002.

QIRC (2007) Final Report: Queensland Pay Equity Inquiry - the impact of Workchoices on women, 2007, available at <http:/www.qirc.qld.gov.au/ inquiry/pay_equity/final/final_report.htm>, accessed 20 March 2009.

Queensland Government (2006) Submission to Queensland Industrial Relations Commission Progressing Pay Equity: An Inquiry, 15 June 2006.

Ronalds, C. (1991) Affirmative Action and Sex Discrimination, $2^{\text {rd }}$ edn, Sydney: Pluto Press.

Ronalds, C. (2008) Discrimination Law and Practice, $3^{\text {rd }}$ edn, Sydney: Federation Press. 
Ryan, E. and Conlon, A. (1989) Gentle Invaders: Australian Women at Work, Ringwood, Vic: Penguin.

Scutt, J. (1990) Women and the Law, Sydney: Law Book.

Sheridan, T. and Stretton, P. (2004) 'Mandarins, Ministers and the Bar on Married Women', Journal of Industrial Relations, 46 (1), 84-101.

Short, C. (1986) 'Equal Pay - What Happened?' Journal of Industrial Relations, 28 (3), 315-335.

Strachan, G. (1996) Labour of Love: The History of the Queensland Nurses' Association in Queensland 1860-1950, Sydney: Allen and Unwin.

Strachan, G., Burgess, J. and Henderson, L. (2010) 'Work and family policies: Balance, collision or compromise', in G. Strachan, E. French and J. Burgess, (eds), Managing Diversity in Australia: Theory and Practice, Sydney: McGraw Hill, 89-106.

Strachan, G., Burgess, J. and Henderson, L. (2007) 'Equal Employment Opportunity Legislation and Policies: the Australian Experience', Equal Opportunities International, 26 (6), 525-540.

Strachan, G., French, E. and Burgess, J. (2010) 'Managing Diversity: Origins and Development', in G. Strachan, E. French and J. Burgess, (eds), Managing Diversity in Australia: Theory and Practice, Sydney: McGraw Hill, 1-15.

United Nations (2010), 30 Years United Nations Convention on the Elimination of all Forms of Discrimination against Women, available at <http://www.unifem.org/cedaw30/>, accessed 18 January 2010.

Whitehouse, G. (2004) Pay Equity - 20 Years of Change and Continuity, Human Rights and Equal Opportunity Commission, unpublished paper. 
Glenda Strachan is Professor, Department of Employment Relations and Human Resources, Griffith Business School, and member of the Work, Organisation and Wellbeing Research Centre ar Griffith University, Queensland. She has developed a body of research on contemporary and historical workplace change especially issues that relate to women's working experiences, and published in international and Australian journals including Labour History, Continuity and Change, British Journal of Industrial Relations, and Equal Opportunities International. Her books are Managing Diversity in Australia: Theory and Practice (2010 with French and Burgess) and Labour of Love: The History of the Nurse's Association in Queensland 1850 - 1950, (1996). Prior to becoming an academic she worked with trade unions.

Robyn Jorgensen is CEO of the Nyangatjatjara Aboriginal Corporation, Yulara, NT and a member of the Griffith Institute for Educational Research and Institute for Social \& Behavioural Research, and an extensive record in researching equity and justice issues.

Peter Grootenboer is a member of the Griffith Institute for Educational Research and Institute for Social \& Behavioural Research, and his research focuses on the teaching and learning of mathematics.

Peter Sullivan is a member of the Centre for Science, mathematics and Technology Education at Monash University and has a particular interest in classroom based research on the teaching of mathematics. 
Reproduced with permission of the copyright owner. Further reproduction prohibited without permission. 